\section{Ulinastatin reduces elevation of cytokines and soluble adhesion molecules during cardiac surgery}

Takae Kawamura MD PhD, Katsuya Inada PhD, Noriko Akasaka MD, Reiji Wakusawa MD PhD
Purpose: To investigate whether ulinastatin pretreatment (6000 U. $\mathrm{kg}^{-1}$ before CPB and before declamping of aorta) influenced the production of cytokines and adhesion molecules in the peripheral circulation.

Methods: This prospective randomized study was performed in 22 patients undergoing cardiac surgery. They were divided into two groups. Patients in Group I were untreated and in Group II treated with ulinastatin. The soluble intercellular adhesion molecule-I (S-ICAM-I), soluble endothelial leukocyte adhesion molecule-I (S-ELAM-I), interleukin8 and 6 (IL8,6) were measured using ELISA kits.

Results: Serum S-ICAM-I concentration in Group I increased from the preoperative value of $297 \pm 27 \mathrm{ng} \cdot \mathrm{kg}^{-1}$ to $418 \pm$ $106 \mathrm{ng} \cdot \mathrm{kg}^{-1}$ at $60 \mathrm{~min}$ after declamping of the aorta $(P<$ $0.01)$ but did not change in Group II. Serum S-ELAM-I concentration did not change in either group. Serum concentration of $\mathrm{L}-8$ and $\mathrm{L} L-6$ in Group $/\left(37 \pm 44 \mathrm{pg} \cdot \mathrm{kg}^{-1}\right.$, and $59 \pm$ $59 \mathrm{pg} \cdot \mathrm{kg}^{-1}$, preoperatively) increased to $169 \pm 86 \mathrm{pg} \cdot \mathrm{kg}^{-1}$ and $436 \pm 143 \mathrm{pg} \cdot \mathrm{kg}^{-1}$ at $60 \mathrm{~min}$ after declamping of the corta $(P<0.001, P<0.001)$. The increases were greater than those from $25 \pm 6 \mathrm{pg} \cdot \mathrm{kg}^{-1}$ and $30 \pm 26 \mathrm{pg} \cdot \mathrm{kg}^{-1}$ to $56 \pm 36$ $\mathrm{pg} \cdot \mathrm{kg}^{-1}$ and $132 \pm 78 \mathrm{pg} \cdot \mathrm{kg}^{-1}$ in Group $/ I(P<0.001, P<$ $0.001)$. The levels of S-ICAM-I correlated with those of IL-8 (r $=0.5, P<0.001$ )

\section{Key words}

ANAESTHESIA: cardiac, cardiopulmonary bypass; DRUG: ulinastatin, protease inhibitor;

HEART: reperfusion injury;

IMMUNOLOGY: cytokines, adhesion molecules (S-ICAM-

$$
\text { I, S-ELAM-I). }
$$

From the Department of Anaesthesia, School of Medicine, Iwatc Medical University, Iwate, Japan.

Address correspondence to: Dr. T. Kawamura, Department of Anesthesia, School of Medicine, Iwate Medical University, 19-1, Uchimaru, Morioka, Iwate 020 Japan.

Phone: 81-196-51-5111. Fax: 81-196-23-4112.

Accepted for publication 2/st December, 1995.
Conclusion: These results suggest that ulinastatin may suppress the increase in $I L-8$ production and the expression of ICAM-I during cardiac surgery.

Objectif: Rechercher si le l'administration préalable d'ulinastatin $\left(6000 \mathrm{U} \cdot \mathrm{kg}^{-1}\right.$ avant la CEC et au déclampage de l'aorte) influençait la production de cytokines et de molécules adhésives dans la circulation périphérique.

Méthodes: Cette élude prospective et aléatoire a été réalisée chez 22 patients soumis à une chirurgie cardiaque. Ils ont été répartis entre deux groupes. Les patients du groupe I n'ont pas reçu de l'ulinastatin alors que le groupe en a reçu. La molécule-I adhésive intercellulaire soluble (S-ICAM-I), la molécule-I endothéliale leucocytaire soluble (S-ALAM-J), les interleukines 8 et $6(I L-8,6)$ ont été mesurées à l'aide d'une trousse ELISA.

Résultats: La concentration sérique de S-ICAM-I du groupe I a augmenté 60 min après le déclampage de l'aorte de la valeur préopératoire de $297 \pm 27 \mathrm{ng} \cdot \mathrm{kg}^{-1}$ à $418 \pm 106 \mathrm{ng} \cdot \mathrm{kg}^{-1}$ $(P<0,01)$ mais est demeurée inchangée dans le groupe ll. La concentration sérique de IL-8 et IL-6 n'a pas changé dans les deur groupes. Les concentrations sériques de $I L-8$ et $I L-6$ dans le groupe I (valeurs préopératoires $37 \pm 44 \mathrm{pg} \cdot \mathrm{kg}^{-1}$ et $\left.59 \pm 59 \mathrm{pg} \cdot \mathrm{kg}^{-1}\right)$ ont a augmenté à $169 \pm 86 \mathrm{pg} \cdot \mathrm{kg}^{-1}$ et $436 \pm$ $43 \mathrm{pg} \cdot \mathrm{kg}^{-1} 60 \mathrm{~min}$ après le déclampage de l'aorte $(P<0,00 I$, $P<0,001)$. Les niveaux de $S$-ICAM-l étaient en corrélation avec ceux de $I L-8(r=0,5, P<0,00 I)$.

Conclusion: Ces résultats suggèrent que l'ulinastatin peut supprimer l'augmentation de la production de IL-8 et se ICAM-I.

Our previous studies showed ${ }^{1.2}$ that the production of IL-8 and IL-6 increased after declamping the aorta in patients who had undergone cardiac surgery with CPB, and that the increase in these factors correlated with CK-MB concentration, suggesting that IL-8 and IL-6 contributed to reperfusion injury following ischaemia. These inflammatory cytokines are known to potentiate the expression of various adhesion molecules on neutrophils and vascular endothelial cells ${ }^{3.4}$ and, as a result, 
to activate neutrophils and produce or release oxygen free radicals and elastase, which may cause tissue injury. In the present study, we determined soluble adhesion molecules, and evaluated the effect of ulinastatin on the production of S-ICAM-1, S-ELAM-1, IL-8 and IL-6.

\section{Methods}

With institutional approval and informed consent, this prospective randomized study was performed in 22 patients undergoing cardiac surgery: Group I, 10 patients (CABG five, valve disease five cases) underwent standard CPB; Group II, 12 patients (CABG five, valve disease seven cases) received $6000 \mathrm{U} \cdot \mathrm{kg}^{-1}$ ulinastatin (Miracrid ${ }^{\circledR}$, Mochida Ltd., Japan) iv before CPB and before declamping of the aorta.

Preanaesthetic medication included diazepam $(0.2$ $\mathrm{mg} \cdot \mathrm{kg}^{-1}$ ), hydroxyzine (l $\left.\mathrm{mg} \cdot \mathrm{kg}^{-1}\right)$, mepcridine (1 $\left.\mathrm{mg} \cdot \mathrm{kg}^{-1}\right)$ and atropine $\left(0.01 \mathrm{mg} \cdot \mathrm{kg}^{-1}\right)$. Anaesthesia was induced with fentanyl $\left(30 \mu \mathrm{g} \cdot \mathrm{kg}^{-1}\right)$, and tracheal intubation was facilitated with vecuronium $\left(0.15 \mathrm{mg} \cdot \mathrm{kg}^{-1}\right)$. Anaesthesia was maintained using oxygen, and highdose fentanyl (total $100 \mu \mathrm{g} \cdot \mathrm{kg}^{-1}$ ). Ventilation was controlled to maintain $\mathrm{PaCO}_{2}$ at approximately $40 \mathrm{mmHg}$.

The perfusion apparatus included a hollow fibre membrane oxygenator (Terumo, Capiox) and nonpulsatile roller-pump (Pemco Inc.) A mixture of mannitol $20 \%$, sodium bicarbonate $7 \%$, electrolyte solution, and CPD-added preserved blood was used for priming, and then perfused at a flow of $2.4 \mathrm{~L} \cdot \mathrm{m}^{-2} \cdot \mathrm{min}^{-1}$. Haematocrit concentrations were maintained at $20 \%$ or more throughout CPB. Body temperature was cooled down to below $30^{\circ} \mathrm{C}$ by core cooling through $\mathrm{CPB}$. Crystalloid and blood cardioplegia were used for cardiac preservation.

The ECG, EEG, and oesophageal and rectal temperatures were monitored continuously. Arterial blood oxygen saturation was also monitored continuously with a pulse-oximeter (Datex, Satlite), and end-tidal carbon dioxide concentrations with capnography (Datex Capnomac). A pulmonary artery catheter was inserted via the internal jugular vein and a catheter was placed in the radial artery to measure arterial pressure directly. Six arterial blood samples were drawn after induction of anaesthesia at the following times: before surgery, immediately before starting CPB, $60 \mathrm{~min}$ after aortic occlusion, and 60,120 and $180 \mathrm{~min}$ after declamping of the aorta. In each sample, S-ICAM-1, S-ELAM-1, IL-8, and IL-6 concentrations were measured by ELISA kits (S-ICAM-1, S-ELAM-1: British Biotechnology Products Lid., Abingdon, U.K., IL-8: R\&D systems Minneapolis, MN, USA, IL-6: Toray Fujibionics Inc., Tokyo, Japan). For statistical analyses, repeated mea-
TABI_E I Clinical characteristics

\begin{tabular}{lcc}
\hline Group & Control & Ulinastatin \\
\hline Patients & $n=10$ & $n=12$ \\
Age (yr) & $54 \pm 17$ & $63 \pm 11$ \\
BW (kg) & $62 \pm 11$ & $55 \pm 8$ \\
EF (\%) & $50 \pm 23$ & $60 \pm 12$ \\
CPB (min) & $159 \pm 47.4$ & $159 \pm 27$ \\
Aoclamp (min) & $101 \pm 32.6$ & $97 \pm 26$ \\
\hline
\end{tabular}

Mean \pm SD; BW: body weight; EF: ejection fraction; CPB: cardiopulmonary bypass; Ao. clamp: aortic clamp time.

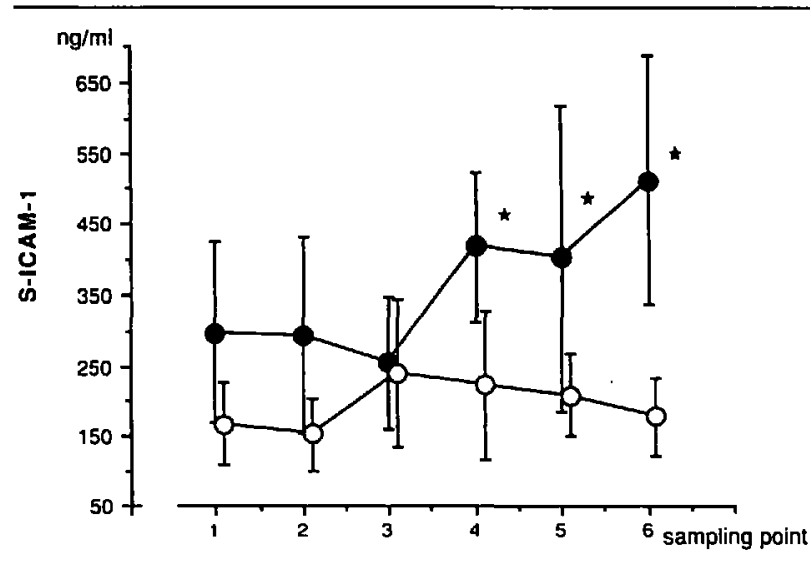

FIGURE 1 Changes of serum soluble ICAM-1 concentration mean SD. $\bullet$ Group I $(n=10)$, O Group II $(n=12) . \star P<0.01$ vs (1) (3). Sampling times: I. before surgery; 2 . before CPB; 3.60 min after aortic occlusion; $4.60 \mathrm{~min}$ after reperfusion; $5.120 \mathrm{~min}$ after reperfusion: $6.180 \mathrm{~min}$ after reperfusion.

sures ANOVA was used for multiple within group comparisons and Student's $\mathrm{t}$ test for between group comparison. Significant difference was defined as $P<0.05$. Data are presented as mean \pm standard deviation (mean \pm SD).

\section{Results}

Patients from the two groups did not differ in terms of age, body weight, ejection fraction, duration of $\mathrm{CPB}$, or aortic clamping time (Table 1 ). The serum concentrations of S-ICAM-I did not change in Group II but increased at $60,120,180 \mathrm{~min}$ after reperfusion (declamping of aorta) compared with the value before surgery and 60 min after aortic occlusion in Group I ( $P$ $<0.01$, Figure 1). Serum S-ELAM- 1 concentration did not change in either group (Table II). Serum lL-8 concentration increased at 60,120 , and $180 \mathrm{~min}$ after reperfusion compared with the values before surgery and 60 min after aortic occlusion in both groups $(P<0.001)$. The IL- 8 concentration in Group II was less than that in 
TABLE II Concentrations of serum IL-8, IL-6 and S-ELAM-1.

\begin{tabular}{lllllllc}
\hline \multicolumn{7}{c}{ Sampling points } \\
\cline { 2 - 8 } & Group & $I$ & 2 & 3 & 4 & 5 & 6 \\
\hline IL-8 $\left(\mathrm{pg} \cdot \mathrm{ml}^{-1}\right)$ & Group I & $37.7 \pm 44.2$ & $37.2 \pm 27.0$ & $60.3 \pm 36.9$ & $169.5 \pm 86.5^{*}$ & $169.0 \pm 77.0^{*}$ & $113.6 \pm 78.6^{*}$ \\
& Group II & $25.0 \pm 6.6$ & $25.1 \pm 18.5$ & $26.1 \pm 24.7$ & $56.3 \pm 36.4^{*} \dagger$ & $49.8 \pm 30.8^{*} \dagger$ & $44.9 \pm 31.2^{*} \dagger$ \\
$\mathrm{IL}-6\left(\mathrm{pg} \cdot \mathrm{ml}^{-1}\right)$ & Group I & $59.8 \pm 59$ & $64.0 \pm 52.1$ & $252.1 \pm 159.6$ & $436.5 \pm 143.5^{*}$ & $390.3 \pm 114.2^{*}$ & $332.4 \pm 109.6^{*}$ \\
& Group II & $30.7 \pm 26.8$ & $25.0 \pm 25.1$ & $22.3 \pm 19.4$ & $132.8 \pm 78.0^{*} \dagger$ & $167.9 \pm 146.0^{*} \dagger$ & $153.0 \pm 66.7^{*} \dagger$ \\
S-ELAM-1 $\left(\mathrm{ng} \cdot \mathrm{ml}^{-1}\right)$ & Group I & $38.0 \pm 12.7$ & $40.3 \pm 13.8$ & $41.9 \pm 14.7$ & $50.6 \pm 17.8$ & $41.5 \pm 5$ & $51.1 \pm 21.7$ \\
& Group II & $37.3 \pm 21.3$ & $39.5 \pm 23.1$ & $42.3 \pm 22.9$ & $40.9 \pm 21.4$ & $35.4 \pm 15.3$ & $40.3 \pm 14$ \\
\hline
\end{tabular}

Sampling Points (1) before surgery (2) before CPB (3) 60 min after Aortic occlusion (4) $60 \mathrm{~min}$ after reperfusion (5) 120 min after reperfusion (6) 180 min after reperfusion. Mcan \pm SD. ${ }^{*} P<0.001$ vs $(1),(3), \uparrow P<0.01$ vs Group 1.

Group I at each time after reperfusion $(P<0.01$, Table II). Serum concentrations of IL-6 increased at $60 \mathrm{~min}$ after reperfusion compared with the values before surgery and $60 \mathrm{~min}$ after aortic occlusion and remained increased until $180 \mathrm{~min}$ after reperfusion in both groups $(P<0.001$, Table II). The IL-6 concentrations in Group II were less than those in Group I at each time after reperfusion $(P<0.02$, Table II). The serum S-ICAM-1 concentration correlated with the $\mathrm{LL}-8$ concentration $(\mathrm{r}=$ $0.5, P<0.01, n=60$, Figure 2), but not with the IL-6 concentration in Group I. The cardiac index (CI) was higher in Group II $\left(3.4 \pm 0.36 \mathrm{~L} \cdot \mathrm{min}^{-1} \cdot \mathrm{m}^{-2}\right)$ than in Group I $\left(2.9 \pm 0.69 \mathrm{~L} \cdot \mathrm{min}^{-1} \cdot \mathrm{m}^{-2}\right)(P<0.05)$ and pulmonary capillary wedge pressure (PCWP) was lower in Group II $(10.4 \pm 4.8 \mathrm{mmHg})$ than in Group I $13.7 \pm 3.0$ $\mathrm{mmHg}(P<0.05)$ on the first day after cardiac surgery. Doses of catecholamine used after cardiac surgery were not different between groups.

\section{Discussion}

Neutrophil and endothelial cell adhesion is mainly mediated by two pathways 5 : one is the LECAM (leukocyte-endothelial cell adhesion molecules) family molecules and sugar residue, and the other is CD-18 and ICAM-1. Adhesion takes place in several steps: (1) tethering, (2) triggering, (3) adhesion, and (4) migration. ${ }^{6}$ The LECAM family molecules, such as LECAM-1 and ELAM-1, play an important role in tethering, while integrin family molecules, such as LFA-1 and Mac-1 on leukocytes contribute to the adhesion of leukocytes and vascular endothelial cells. ${ }^{7}$ The LECAM family molecules attract unstimulatd leukocytes in the circulation to the activated vascular endothelium. They induce rolling of leukocytes on the endothelium, ${ }^{8}$ and then activate them with leukocyte chemotactic factors, such as IL-8 and platlet activating factor (PAF) which are produced and released from the endothelium. Activated leukocytes express Mac-1 on their surfaces, and then adhere dependently to LECAM-1 or CD-18/ICAM-1 which

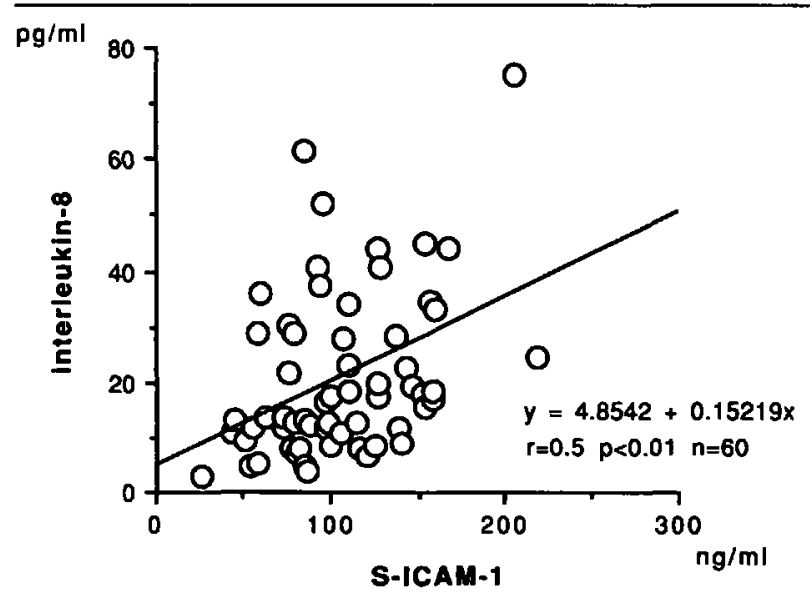

FIGURE 2 Correlation between serum IL-8 and soluble ICAM-1 concentration in Group I. $n=60 \mathrm{r}=0.5 P<0.001$

proceeds to migration. The expression and function of these adhesion molecules may be regulated by cytokines. Cytokines such as TNF- $\alpha$, IL- $1, \mathrm{IL}-4, \mathrm{IL}-6$ and IL-8 have been reported to potentiate the expression of VCAM-1, ICAM-1 and ELAM-1 on endothelial cells. ${ }^{9}$ The present study showed that IL-8, IL-6 and S-ICAM1 increased after ischaemic reperfusion and that IL-8 correlated positively with S-ICAM-1. These results support the hypothesis that the production of IL-8 is increased after ischaemia and that S-ICAM-1 is then upregulated. It has been reported that IL-8 is induced in the myocardium after ischaemia and reperfusion in $v^{\text {vivo }}{ }^{10}$ and up-regulates adhesion molecules. ${ }^{9}$ Smith $e t$ al., ${ }^{11}$ reported that the ELAM-1 mediated pathway was quickly suppressed after adhesion of neutrophils to endothelial cells, and disappeared within $30 \mathrm{sec}$, to be replaced by the CD- 18 and ICAM-1 mediated pathway. In our study, S-ELAM-1 did not change. This may be explained as follows: S-ELAM- 1 may have been elevated but disappeared quickly and, in addition, ELAM-1 
was not detected directly on the endothelium, but soluble ELAM-1 was measured indirectly, and therefore its changes could not be followed. Ulinastatin, which is isolated from human urine, inhibits trypsin, and pancreatic elastase activity, ${ }^{12}$ polymorphonuclear leukocyte elastase activity ${ }^{13}$ and the endotoxin-stimulated production of tumour necrosis factor alpha and interleukin $1 .^{14}$ Moreover, it has an anti-shock effect similar to steroid hormones. ${ }^{15}$ Endo et al., ${ }^{16}$ reported that ulinastatin inhibited production of polymorphonuclear leukocyte elastase and IL-8. In a previous study, we investigated the inhibitory effects of ulinastin on the increased production of IL-8 and IL-6 during cardiac surgery with cardiopulmonary bypass. ${ }^{17}$ Also, IL-8 and IL-6 have been reported to potentiate the expression of adhesion molecules. In the present study, we observed the effects of ulinastatin on the soluble adhesion molecules following suppression of IL- 8 and IL-6 production. As a result, in patients receiving pretreatment with ulinastatin, the increases in the production of IL-8 and IL-6 were suppressed, and S-ICAM-1 did not change after reperfusion. There was a positive correlation observed between IL-8 and S-ICAM-1. These results suggest that ulinastatin prevented up-regulation of S-ICAM-I by inhibiting the increased production of IL-8.

Hennein et al. ${ }^{18}$ reported that inflammatory cytokines, such as IL-8 and IL-6, are elevated during coronary revascularization and may contribute to postoperative myocardial ischaemia and segmental wall motion abnormalities. We have reported a negative correlation between serum IL- 8 and postoperative cardiac index and suggested that elevation of IL-8 during cardiac surgery caused posioperative cardiac dysfunction. ${ }^{2}$ Also, the expression of ICAM-1 on cardiac myocytes was induced by IL- 6 and adhesion of leukocytes to myocytes was potentiated by IL-6. In this respect, it is suggested that IL-6 is involved in reperfusion injury. The clinical importance of these findings is that suppression of increased production of inflammatory cytokines and adhesion molecules by pretreatment with ulinastatin may produce myocardial protection. We observed, in ulinastatin-treated patients, that postsurgical cardiac index was higher and PCWP was lower than in untreated patients. Nevertheless, the total doses of cathecholamines used after cardiac surgery were not different between groups. As C.I. is negatively correlated with maximum concentration of IL-8 during surgery, ${ }^{2}$ ulinastatin pretreatment may improve post-surgical cardiac function by suppressing increased the production of IL8 and S-ICAM-1.

\section{References}

I Kawamura T, Wakusawa R, Okada K, Inada K. Ele- vation of cytokines during open heart surgery with cardiopulmonary bypass: participation of interleukin 8 and 6 in reperfusion injury. Can J Anaesth 1993; 40; 1016-21.

2 Kawamura $T$, Inada $K$, Okada $H$, Okada $K$, Wakusawa $R$. Methylprednisolone inhibits increase of interleukin 8 and 6 during open heart surgery. Can J Anacsth 1995: 42; 399403.

$3 \operatorname{Rot} A$. Endothelial cell binding of NAP-1/IL-8: role in neutrophil emigration. Immunol Today 1992: 13; 291-4.

4 Paccaud J-P, Shifferli JA, Baggiolini M. NAP-1/IL-8 induces up-regulation of CRI receptors in human neutrophil leukocyles. Biochem Biophys Res Commun 1990: 166; 187-92.

5 Abbassi $O$, Lane $C L$, Krater $S$, et al. Canine ncutrophil margination mediated by lcctin adhesion molecule- 1 in vitro. J Immunol 1991: 147; 2107-15.

6 Shimizu Y, Newman W, Tanaka Y, Shaw S. Lymphocyte interactions with endothelial cells. Immunol Today 1992: 13; 106-12.

7 Diamond MS, Stauton DE, de Fourgerolles AR, et al. ICAM-1 (CD54): A counter-receptor for Mac-1 (CDI lb/CDI8). J Cell Biol 1990: 111; 3129-39.

8 Lawrence $M B$, Springer TA. Leukocytes roll on a selectin at physiologic flow rates: distinction from and prerequisitc for adhesion through integrins. Cell 1991: 65; 859-73.

9 Tanaka Y, Adams DH, Shaw S. Proteoglycans on endothelial cells present adhesion-inducing cytokines to leukocytes. Immunol Today. 1993: 14; 111-5.

10 Kukielka GL, Smith CW, LaRosa GJ, et al. Interleukin-8 gene induction in the myocardium after ischemia and referfusion in vivo. J Clin Invest 1995: 95; 89-103.

11 Smith $C W$. Transendothelial migration, $I n$ : Harlan JM, Liu DY (Eds.). Adhesion lts Role in Inflammatory Disease. New York: Frecman and Company, 1992: 103.

12 Ogawa M, Nishibe S, Mori T, Neumann S. Effect of human urinary trypsin inhibitor on granulocytc elastase activity. Research Communications in Chemical Pathology and Pharmacology 1987: 55; 271-4.

13 Hamazaki K, Matsubara N, Yunoki Y, Mori M, Mimura H, Orita $K$. Effects of ulinastatin on polymorphonuclear leukocyte elastase and interleukin 6 level after hepatectomy. Clin Ther 1994: 16; 680-5.

14 Endo S, Inada $K$, Taki $K$, Hoshi S, Yoshida M. Inhibitory effects of ulinastatin on the production of cytokines: implications for the prevention of septicemic shock. Clin Ther 1990: 12; 323-6.

15 Nakajima $K$ and Goto $Y$. Differentiation of the anti-schock effect of ulinastatin from steroid hormone by the continuous observation of microcirculation dynamics. Circ Shock 1992: 36; 284-9.

16 Endo S, Inada K, Yamashita H, et al. The inhibitory actions of protcasc inhibitors on the production of poly- 
morphonuclear leukocyte elastase and interleukin 8.

Research Communications in Chemical Pathology and Pharmacology 1993: 82; 27-34.

17 Kawamura T, Inada K, Kimura O, Akaska N, Wakusawa $R$. The inhibitory effects of ulinastatin on the increase of interleukin 8 and 6 during open heart surgery (Japanese). Masui 1994: 43; 1818-23.

18 Hennein HA, Ebba H, Rodriguez JL, et al. Relationship of the proinflammatory cytokines to myocardial ischemia and dysfunction after uncomplicated coronary revascularization. J Thorac Cardiovasc Surg 1994: 108; 626-35. 